University of Glasgow; Dr. F. R. Smith, research director, T. and H. Smith, Ltd., Edinburgh; Dr. H. C. Sutton, senior lecturer in radiochemistry, University of Edinburgh; Dr. R. H. Thomson, senior lecturer in chemistry, University of Aberdeen; Dr. G. R. Tristram, senior lecturer in biochemistry, University of St. Andrews; Mr. P. Wildy, assistant director, Medical Research Council Experimental Virus Research Unit; Prof. W. Wright, professor of civil engineering, Trinity College, Dublin.

\section{The International Academy of Astronautics}

THE following have been elected members of the International Academy of Astronautics of the International Astronautical Federation.

Basic Sciences Section: Prof. Harrison S. Brown, California Institute of Technology; Prof. André L. Danjon, director, Astronomical Observatory, Paris; Dr. Audouin Dollfus, Paris Observatory, Meudon; Prof. T. Gold, Cornell University, Ithaca; Dr. Robert Jastrow, director, Institute for Space Studies, New York; Mr. D. G. King-Hele, Royal Aircraft Establishment, Farnborough; Dr. Zdenek Kopal, University of Manchester; Dr. Gerard P. Kuiper, director, Lunar and Planetary Laboratory, University of Arizona, Tucson; Dr. David F. Martyn, head, Upper Atmosphere Section, CORESEARCH, Camden (Australia); Prof. Donald H. Menzel, director, Astronomical Observatory, Harvard University, Cambridge, Mass.; Prof. Cecil F. Powell, University of Bristol; Prof. G. Righini, director, Arcetri Astrophysical Observatory, Florence; Dr. Walter Orr Roberts, National Center for Atmospheric Research, Boulder; Prof. John A. Simpson, Enrico Fermi Institute for Nuclear Studies, University of Chicago; Prof. S. Fred Singer, University of Maryland; Dr. Richard Tousey, Atmospheric and Astrophysics Division, U.S. Naval Research Laboratory, Anacostia; Dr. Albrecht Unsöld, University of Kiel; Prof. E. Vassy, University of Paris; Prof. Fritz Zwicky, California Institute of Technology.

Engineering Sciences Section: Dr. Arthur C. Clarke, former chairman, British Interplanetary Society (at present in Colombo, Ceylon); Dr. Charles S. Draper, Massachusetts Institute of Technology, Cambridge, Mass.; Prof. Carlo Ferrari, Polytechnic Institute of Turin; Prof. B. Fraeijs de Veubeke, Universities of Liége and Louvain; Dr. W. Jost, University of Göttingen; Prof. Hubert Schardin, director, Research Institute of St. Louis, France; Dr. A. Silverstein, Lewis Research Center, Cleveland; Dr. Homer J. Stewart, California Institute of Technology; Sir Geoffrey Taylor, University of Cambridge; Prof. Stephen Timoshenko, Palo Alto, California.

Life Sciences Section: Prof. Grigore Benetato, director, Institute of Normal and Pathological Physiology, Bucarest; Dr. Hilding A. Bjurstedt, Karolinska Institute, Stockholm; Col. Paul A. Campbell, U.S.A.F. Aerospace Medical Center, Brooks Air Force Base, San Antonio; Dr. Carl-Johan Clemedson, University of Gothenburg; Mr. Arthur Dean, lawyer, Sullivan and Cromwell, New York; Prof. Jakob Eugster, former professor of physiology, Muri/Berne; Dr. Siegfried J. Gerathewohl, Ames Research Center, Moffett Field; Dr. Vladimir Kopal, Institute of State and Law, Czechoslovak Academy of Sciences, Prague; Dr. Ulrich Luft, Foundation for Medical Education and Research, Albuquerque (United States); Mr. David F. Maxwell, lawyer, Obermayer, Rebmann, Maxwell and Hippel, Philadelphia; Dr. Michel Smirnoff, Foreign Trade Research Insti- tute, Belgrade; past-president International Institute of Space Law (Yugoslavia); Dr. M. V. Strumza, University of Paris; Dr. Heinz von Diringshofen, University of Frankfort.

\section{The Nature Conservancy}

Lord Howick of Glendale has been appointed chairman of the Nature Conservancy in succession to Lord Hurcomb, who is retiring from the Conservancy after serving for eight years as a member and as chairman of the Committee for England, and for a further year as chairman of the Conservancy. Lord Howick (formerly Sir Evelyn Baring) became a member of the Conservancy in 1961 and is also chairman of the Colonial Development Corporation. The following have been appointed members of the Nature Conservancy: Lieut.-Colonel J. P. Grant, Sir Charles G. Connell and Mr. T. F. Peart. The vacancies have arisen through the retirement of Lord Hurcomb, Sir Basil Neven-Spence and Mr. G. R. Chetwynd. Sir Charles Connell, who (like Lieut.-Colonel Grant) is already a member of the Scottish Committee, becomes its chairman, and Sir James Denby Roberts joins it as a new member on the retirement of Sir Basil Neven-Spence. Mr. H. G. Hurrell and Mr. P. F. Holmes will join the Committee for England. On the Committee for Wales, Mr. Llywelyn Phillips and Mr. G. T. Goodman succeed Prof. W. Ellison and the late Mr. W. Vaughan Lewis. Lord Howick, Sir Charles Connell and Prof. R. O. Buchanan have been appointed to the Scientific Policy Committee.

\section{G.E.C. (Research), Ltd.}

The General Electric Co., Ltd., has formed a subsidiary company to manage its research activities. The new Company is to be known as G.E.C. (Research), Ltd., and will be under the chairmanship of Mr. O. W. Humphreys. Mr. V. J. Francis, who succeeds Mr. Humphreys as director of the Central Research Laboratories and administrative head of the Hirst Research Centre, has been appointed executive director. Mr. Francis was educated at the Sir Joseph Williamson School, Rochester, from which he obtained a State Scholarship and a Royal Scholarship, and proceeded to the Imperial College of Science and Technology, graduating first in mathematics and later in physics, both with first-class honours. $\mathrm{He}$ joined the Research Laboratories of the G.E.C. in 1931 and was promoted to the leading scientific staff in 1937. His work concerned numerous projects involving lamps, gas discharges, very high power carbon arcs, and special valves and cathode ray tubes for radar equipment. After the War he was in charge of the Lamp and Cathode Ray Tube Departments of the Laboratories. He became manager of the Physics Division in 1953 and was appointed a deputy director in 1960 , at the time when the Laboratories were reorganized as the Hirst Research Centre.

\section{Post Office Engineering Department:}

Mr. C. E. Richards

Mr. C. E. Richards, who in 1958 became the first holder of the post of deputy director of research, Post Office Engineering Department, retired on December 29,1961 . In 1923, after a short career in the chemical industry, he became the first professional chemist in the Post Office, and throughout his official career was responsible for research into the properties and applications of materials in Post Office practice. The investigation, which he led, of a serious gas explosion focused attention on the importance of 